\title{
Ten Years Of Preventive Geriatric Services In The City Of Germiston
}

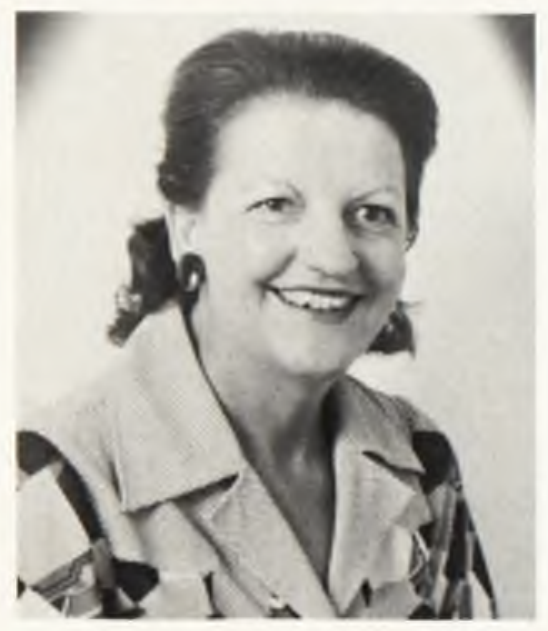

\author{
INTRODUCTION
}

\author{
C. A. Erasmus, M.B. B.Ch., D.P.H. \\ Medical Officer of Health
}

\section{OPSOMMING}

Die Voorkomende Gemeenskapsgeriatriesedienste wat vir die afgelope tien jaar in die Stad Germiston gelewer word, word kortliks uiteengesit. Hierdie dienste is beskikbaar aan alle inwoners van die Stad wie ouer as 60 jaar is en bestaan, onder andere, uit siftingskliniekdienste en voetkundige dienste. Daar word ook tuisbesoeke gedoen om kontak te hou met bejaarde kliënte sowel as om met hul probleme, indien enige, behulpsaam te wees. 'n Register van alle bejaarde persone woonagtig in die Stad, is oor die jare opgestel en daar is tans 1691 persone op hierdie Register. Pogings word aangewend om toepaslike geriatriese dienste vir ouderwordende swart persone woonagtig in Katlehong en Tembisa, die twee groot swart woongebiede waarin die Gesondheidsdepartement dienste lewer, op te bou.

"A human being would certainly not grow to be 70 or 80 years old if this longevity had no meaning for the species.

The afternoon of life must also have a significance of its own and cannot merely be a pitiful appendage of life's morning",

\section{G. Jung - Stages of Life}

$\mathbf{T}$ HE deficiencies in the health care delivery system for the aged in our various population groups to a large extent arises as a result of the three tier system of health responsibility in operation in South Africa up to the present. ${ }^{1}$ The Health Act No. 63 of 1977 will perhaps remedy this situation once it is fully implemented but at present there are very definite shortcomings in the existing medical services available to the aged. The quality of these medical services also varies from Province to Province and also within individual Provinces due to the absence of a national policy based on recognised principles of geriatric care. ${ }^{2}$

As disease patterns amongst the various population groups have changed, Local Authority health services should change in emphasis to deal with new health challenges. I should like to quote from a paper which I presented to the Sixth Biennial Congress of the South African Nursing Association in $1968 .^{3}$ "I consider that a basic need in South Africa is the establishment of geriatric clinics at Local Authority Health Departments to co-ordinate with similar clinics which should exist at hospitals. The Local Authority Clinic should provide health education for the elderly, physiotherapy and periodic medical health checks. Old persons found to require treatment, should then be referred to hospital geriatric clinics for further investigation and follow-up. The Local Authorities already employ trained staff in the persons of their public health nurses who should be aware of the old people in their community, just as they are aware of the babies. They should be an invaluable link in co-ordinating the clinic services for the aged, and should act as liaison officers with general practitioners and district surgeons in the promotion of the health of the aged".

I am as strongly convinced of the validity of the above opinion today, as I was when I expressed it ten years ago. I do not agree that the provision of increasing numbers of institutions to care for the aged is the answer to dealing with the needs of this growing population group, but feel that the 
provision of community services for the elderly to enable them to maintain themselves as independently as possible, should be an urgent national priority. ${ }^{4}$ In an effort to demonstrate that a Local Authority can provide a successful preventive geriatric service, a description of such a service which has been in operation in the City of Germiston for the past 10 years is given below:

\section{THE PREVENTIVE GERIATRIC CLINIC SER VICE IN GERMISTON}

In the 1968 Annual Report of the Medical Officer of Health of Germiston, a chapter was devoted to the needs of the increasing number of older persons in the Republic of South Africa in general and of those older citizens living in Germiston in particular. Mention was made of the fact that during 1968, a total of 276 home visits to older residents had been made by the Health Department's community health nurses and that arising out of these visits an urgent need had been demonstrated for the establishment of a preventive geriatric clinic service in the City. A preventive geriatric clinic session was established once a week and at this clinic session, which was open to white males and females of 60 years and older, eight screening tests were carried out on attenders, by the community health nurse in charge of the Clinic.

It was clearly explained to patients that these screening examinations were preventive in nature and any pathology detected would be referred to the appropriate channels for treatment. It was decided that the following areas could be profitably screened:

(1) Dental Screening: Age is not necessarily a contraindication to dental treatment. ${ }^{5}$ An estimated 22,6 million Americans are edentulous, about half of whom are 65 years of age and over. No figures are available for the South African population. Dental problems of the aged include tissue friability, abnormal taste sensation, post menopausal osteoporosis, excessive bone resorption, delayed wound healing, fungal infections and vague fears and pains relating to the mouth. Simple visual screening of the buccal cavity will identify most of these problems or even the fact that the patient requires attention to ill-fitting or broken dentures.

(2) Screening for Hearing Defects: Many older persons who become hard of hearing become virtual social outcasts. This may be prevented by adequate early intervention when hearing loss is becoming apparent.

(3) Screening for Hypertension: As is well known, essential hypertension may be asymptomatic until the sufferer manifests with an acute cerebro-vascular or cardiovascular episode. Early detection of hypertension and its correction can lessen the risk of such accidents

(4) Screening for Urinary Abnormalities: With the simple urinary test procedures available, conditions such as urinary infections, chronic nephritis, diabetes and cystic polypi amongst other conditions can be readily detected and treated.

(5) Screening for Malnutrition: Either over- or underweight is readily determined and with dietary counselling and social followup, may be rectified.

(6) Screening for Foot Abnormalities: A study carried out on behalf of the British Ministry of Health in 1969. indicated that $78 \%$ of the elderly were estimated professionally as needing chiropody treatment. ${ }^{6}$ No local figures are available, but there is no reason to believe that our aged population is better off than any other as far as the condition of its feet are concerned.

(7) Visual Screening: One of the most important contacts with society is maintained by sight. Older persons with visual defects not only become increasingly housebound and more exposed to domestic and street accidents, but lose their contact with life through the visual media. Those who have formerly maintained an output of items by handicraft, lose this valuable and occupationally therapeutic outlet.

(8) Haemoglobin Screening: Iron deficiency anaemia is the most common cause of anaemia in the elderly and may be due to chronic blood loss from a hiatus hernia, carcinoma of the stomach or colon, diverticulitis, or from taking drugs, for example, aspirin which may cause bleeding. Malnutrition and poor absorption of iron can also be causes when anaemia is diagnosed. Its cause must be established amongst this range of possibilities and steps taken to remedy it.

\section{FINDINGS AT THE PREVENTIVE GERIATRIC CLINIC SER VICE}

At the first Preventive Geriatric Clinic Session, 6 patients attended and of these I required new dentures, 4 required chiropody, 4 required glasses, 1 had raised blood pressure, 1 was obese and 1 was underweight. From these small beginnings this service has grown to such an extent that during 1978 a total of 6138 domiciliary visits were made to persons 60 and over in the City.

The following table indicates the volume of work at Clinic Sessions over the year.

\section{PREVENTIVE GERIATRIC CLINIC SESSIONS}

$\begin{array}{lcccr}\text { Age of clients } & \mathbf{6 0 - 6 9} \text { yrs. } & \mathbf{7 0 - 7 9} \text { yrs. } & \mathbf{8 0 - 8 9} \text { yrs. } & \text { Total } \\ \text { 1st Attendance } & 200 & 137 & 40 & 377 \\ \text { Re-Attendances } & 417 & 453 & 168 & 1038 \\ \text { Chiropody: 1st Attendance } & 53 & 34 & 14 & 101 \\ \quad \text { Re-Attendances } & 329 & 443 & 146 & 918 \\ \text { Other pathology detected: } & 178 & 128 & 38 & 344 \\ \text { Seen by doctor: } & & & & \\ \quad \text { Ist Attendance } & 43 & 80 & 27 & 150 \\ \text { Re-Attendances } & 107 & 131 & 44 & 282\end{array}$




\section{GERIATRIC REGISTER}

In order to try to establish how the elderly are managing in our city and to plan community health services for the future, it was decided to compile and keep up to date a Geriatric Register. At present there are 1691 persons over the age of 60 on the Register with whom contact is maintained at least once a year. which the old black inhabitants of these two townships require.

Three of the community health nurses, working in Germiston, have recorded their own impressions of the work which they do in connection with the Department's Geriatric Services and these reports follow.

\title{
GERIATRIC SERVICES IN KATLEHONG AND TEM- BISA
}

Since 1974 a start has been made with the establishment of black preventive geriatric services in Katlehong and Tembisa. the two black townships in which this Health Department renders preventive health services and every effort is being made to develop the specialised geriatric services

\section{Tracing The Aged In A Community}

\author{
E. K. Blomerus, R.G.N., R.M., \\ Diploma in Public Health \\ Community Health Nursing Sister
}

The estimated white population of Germiston for the year 1978 was 92014 . Based on this population figure, it is to be expected that approximately 8000 persons will be aged 60 years and over, and are potential clients of a Preventive Geriatric Service. As has already been mentioned, the Germiston Health Department has instituted a Register of persons known to be 60 years of age and over. The persons so registered are not all necessarily people who utilise the Department's Preventive Geriatric Service, but are merely recorded in the hope that eventually all persons falling within this age category will be known to the Department for future planning purposes. It is not possible to compile this information in any other way than to conduct a census and such an undertaking falls outside the scope of a Local Authority health department. For this reason, this Department has to rely on other means of contacting older residents of the city.

Over the years we as community health nurses have come into contact with many old people in the course of our normal duties. Home visits, well-baby clinics, birth follow-ups, immunisation clinics, cancer screening clinics and even family planning clinics all create situations where we come into actual contact with older members of the community, or else learn of their present situation. By these direct or indirect contacts we constantly inform our older citizens of the existence of the Preventive Geriatric Clinic and the services which they can obtain through this clinic. Despite the fact that the service has been in operation for 10 years, we still find that many people are unaware of its existence.

On doing a home visit we attempt to make this a truly family affair, and to acquaint ourselves as far as possible with all the persons living in the particular home. We frequently find that not one, but two families actually live together and a variety of aunts, uncles, cousins and grandparents are under the same roof. Family members may be spinsters, widows, widowers or divorced persons of all ages and often fall within the age-category in which we are particularly interested. On occasion we have found aged family members living under appalling conditions in outbuildings during such visits. We also find dedicated children caring lovingly for aged and infirm parents. In this modern day and age many young mothers work, and we often find that the grandmother brings the baby to the well baby clinic. We thus get to know where the grandmother herself lives, whether her husband is still alive, and frequently are able to establish whether she has other older friends and relatives who live in Germiston and where these people stay.

During the first visit to the mother of a newborn baby the community health nurse may find that the young couple are still living with their parents or even their grandparents. In one such instance I followed up a birth notification of a young

E. K. Blomerus

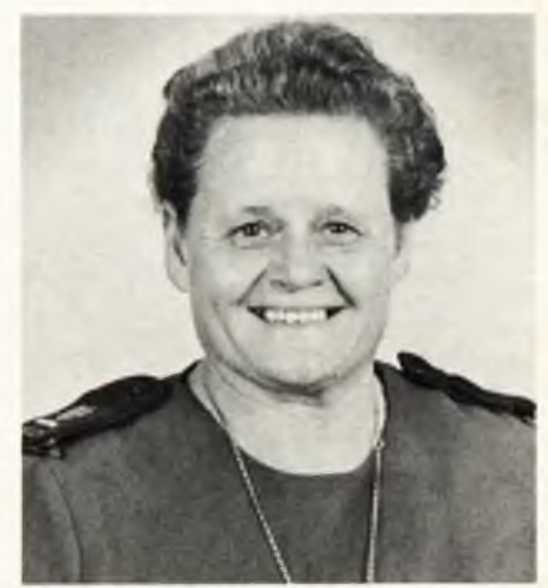


mother aged 16 years living in one of the more affluent suburbs of Germiston. During this visit I found that three generations were living together in the three-bedroomed house. The diningroom had been converted into a bedroom and sleeping bags were kept in the sitting room for the older children to use at night. The paternal great-grandfather aged 68 years, a widower, was the oldest member of the family. The maternal great-grandmother, also well on in her sixties also lived in the house as did the grandmother and grandfather of the newborn infant. The grandparents had five children of their own and supported these children on the grandfather's disability grant. The grandmother who was still too young for an old age pension was referred to the Department of Social Welfare and Pensions for a family allowance, and Council houses were found for the mother and father of the newborn infant and for another young married couple with two children also residents of this "commune". The great-grandfather was referred to the Preventive Geriatric Clinic where he was found to be suffering from a large hernia. He was sent to hospital where this hernia was repaired.

During birth follow-ups we also frequently find that grandparents are visiting the newborn infant to acquaint themselves with this latest addition to the family. Sometimes the grandmother comes to stay for a time to help her daughter with the new baby and other young brothers and sisters. The reverse may also occur, namely a young mother may go and live with her elderly parents whilst her husband is away serving in the army. A situation occurring with increasing frequency and which we have had to deal with on following up a new birth, is one in which we find that the baby is the child of an unmarried mother still at school or university and whose grandmother has undertaken to care for the baby. Where the grandparents are on pension this may place an additional financial burden upon them as the young mother is not yet out earning a living.

Recently the Department decided to intensify the drive to make contact with those older citizens who are not yet known to it. All the community health nurses were given roneoed forms to distribute at their clinics to all adult attenders with the request that the forms be completed and returned to the Department. On the forms information is required concerning any old persons known to be living in Germiston with details of their addresses. This information is then followed up by the geriatric community health nurses.

Thus, whilst not being directly responsible for the Preventive Geriatric Service, the other community health nurses on the Local Authority staff establishment can make a very real contribution both towards making this service known throughout the community and referring clients to the service

\section{A Member Of The Community Geriatric Team}

\section{J. Sudding, R.G.N., R.M.,}

\section{Diploma in Community Health Nursing Science Geriatric Community Health Nursing Sister}

Over the years attitudes towards old age have differed from generation to generation and from country to country. For example, the Bible tells us to "lift up our heads to the face of the old person for even if there is no learning, there is always wisdom of experience." The Eskimos, on the other hand are said to throw their old people into the snow to die. We in Germiston, support the former idea and that is why, in 1968 our own geriatric service was started in a small way. By 1978 we had almost 2000 patients on our books, taking us almost 1 year to follow up each one, individually in his or her home. Basically the aim of our service is to help the aged person to remain in the community for as long as possible.

How do we go about trying to achieve this aim? Firstly. we meet our aged clients and detect any problems that may eventually make them dependent on others. For example, if they need any appliances, such as spectacles, dentures, walking aids, wheel chairs, etc. we help such patients obtain them through the Department of Social Welfare and Pensions. If they can afford these appliances themselves, we advise them where to get them. For those people who do not, for whatever reason, get the State Old Age Pension and are therefore not entitled to free dentures and spectacles, and cannot afford to purchase these items themselves, our Department gets a small grant annually from our City Council in order to assist in the acquisition of these appliances. Once we have detected problems which our Department cannot deal with. we refer the clients to the appropriate community resources. These community resources include hospitals, private doctors, the District Surgeon, the City Council's housing department, or

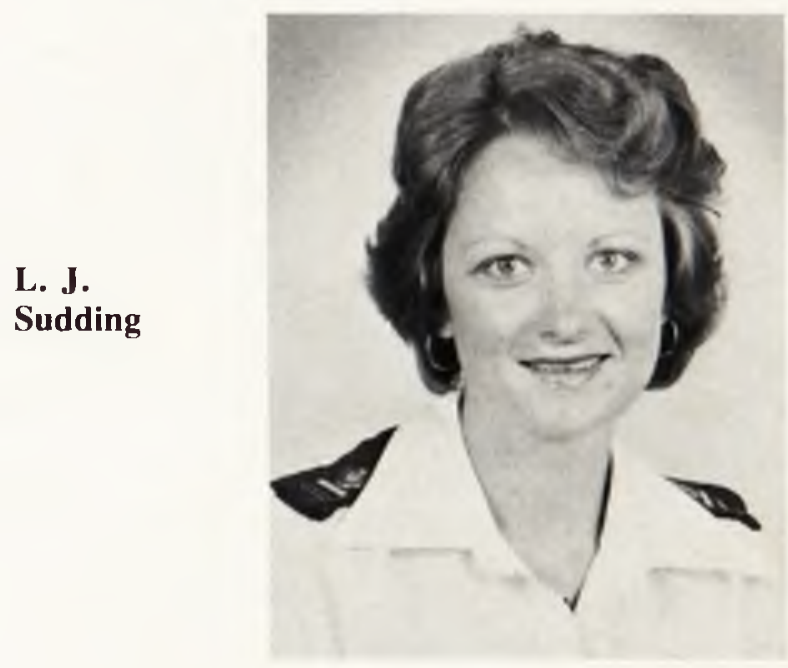


our local Service Centre for the Aged, as well as the Department of Social Welfare and Pensions and old age homes of various kinds. Our own Preventive Geriatric Clinic offers the aged free chiropody services. medical examinations. screening clinics, pap smear clinics and a psycho-geriatric assessment clinic service.

\section{The Chiropody Clinic}

This has proved beyond doubt to be a most valuable and essential service. Statistics show that about $80 \%$ of all persons over 60 have some sort of foot problem ranging from corns to callouses to ingrown toenails. We often see elderly people who are virtually housebound because of these minor foot problems.

\section{The Geriatric Screening Clinic}

This Clinic is held once a week to detect any medical problems. Here the patients' teeth are examined. blood pressure is taken, as well as blood for a haemoglobin estimate. the urine is tested as well as eyes and ears. The patient is weighed and a diet is discussed if necessary. This clinic is conducted by 2 geriatric sisters. but a doctor is on the premises during the clinic sessions so that medical problems can be referred for further opinion.

\section{The Psycho-Geriatric Clinic}

This Clinic was recently started and is becoming more and more popular. Problems seen at the psycho-geriatric clinic are mainly reactive - depressions, due to loss of a spouse, or to failure to adjust to old age and its challenges, as well as a variety of anxiety states. These old patients need regular supportive visits and guidance. but at the same time efforts are made not to allow them to become too dependent on the staff. Regular counselling is given and the aim of this clinic is to help the patient cope with his or her particular problem.

\section{Liaison with Community Resources}

Our Department works very closely with our local Resta-While Service Centre which is run by a Welfare Organisation and which is situated in one of our suburbs known as Primrose. This is the only Service Centre in Germiston which is available to the older citizens.

Members usually arrive at the Centre at about 9 a.m. when they are served with tea and a snack, after which various forms of entertainment are arranged for them, ranging from flower arranging, cookery demonstrations and health education talks. A minister of religion from various church denominations attends the Club twice a week and conducts a service. A physiotherapist employed by the City Council visits the Clinic twice a month and a chiropodist also employed by the City Council renders a session once a week.

The members are provided with a nourishing 3 course meal daily at a fee of 45 cents. After lunch they relax for a while and then go home. The Service Centre has 2 combis and interesting outings are arranged at regular intervals for the members. They are also taken to local hypermarkets where they can buy groceries economically, regularly. The Service Centre also supplies meals-on-wheels which are sent out to old people who have recently been discharged from hospital or who are chronically ill and unable to cook for themselves. A Home Help Service is offered to temporarily incapacitated persons and this service is growing rapidly.

The black home helps are transported in the combis, which are driven by voluntary drivers to the homes of clients, and bath or bedwash those old folk who can no longer bath themselves. They also provide other personal services for the incapacitated old persons who do not want to leave their homes and go into old age homes.

This is where I feel hospitals could play a larger part in rehabilitating older people. So many old people are discharged from hospital into an unknown environment. All hospital nurses, including myself have been trained to take care of the patient while in hospital. but not to involve themselves in knowing where or to whom he or she is going on discharge. So many of us hesitate to get too personal and ask the aged patient questions such as, "who will look after you when you go home?" "will you manage financially?" and finally, "do you have contact with your children, if any. "All these questions are vitally important and while you may think that old Mr Smith is a very quiet and undemanding patient. he may in fact be worrying about problems which he may have when he gets home. If the local Health Department is contacted on the discharge of an older patient the community health nurse can assist and follow-up the patient in the home situation.

Apart from visiting the over 60's in their homes we also visit them in hospitals and old age homes in our area to maintain contact with them. If requested, we give private institutions, caring for the aged, advice on suitable diets and stress the importance of the provision of occupational therapy and physiotherapy for their old inmates. Whilst on the subject of old age homes, it must be stated that one of our biggest problems is actually getting people into these institutions. Germiston has five old age homes. One unsubsidised home charges approximately R200 per month, depending on the income of the patient, thus very few pensioners can afford admission to this home. The other four homes, all of which are subsidised by the Department of Social Welfare and Pensions have lower fees and their waiting lists are extremely long, in some cases up to 8 years. Only one of the five local old age homes admits group $\mathrm{C}$ patients, or so-called frail aged patients. The other homes require the patient to be classified as group A on admission although there are facilities available if the patient should deteriorate and become a group $\mathrm{B}$ or $\mathrm{C}$ patient as time goes by. I advise everyone who turns 60 , to put their names down on a waiting list for an old age home. They need never go into the home, but if the need ever arises. their name is on a waiting list and they have more chance of being admitted. 


\section{Some Interesting Cases Which I Have Dealt With As A Geriatric Health Nurse}

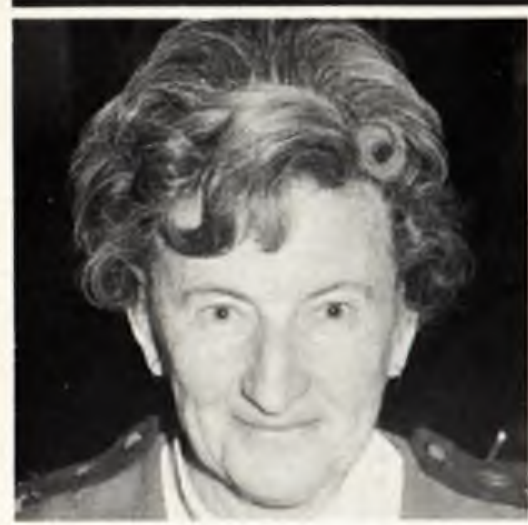

In November 1975 when I was informed that I was to become a geriatric community health nurse amongst the white population of the Germiston community, my reaction was one of dismay and apprehension, as this was a field that I had not specialised in before. Nearing the age of my own retirement I saw in every client a.mirror of what my own life as an aged person could become.

With the general lifespan of the whites increasing and the advent of family planning cutting down the white birthrate, a larger percentage of our community falls into the older age group. For this reason all our nursing staff had been encouraged and also expected to read, attend lectures, talks, films, and provided with other data available on the science of caring for and rehabilitating the aged. As in all types of work, one's own personal approach can determine one's happiness in one's work. Thus, although I regarded this change as a challenge, I approached it with trepidation knowing that my own attitude would either make my clients accept or reject me and any help I might offer.

Our Preventive Geriatric Services had been in operation for many years. Part of my task was to introduce as many people over the age of 60 to our services locally, as well as to acquaint them with Government and Provincial services and other community resources which were available. My work area covered people at all socio-economic levels, from the poor who only had their State pensions to sustain them, to the affluent who could afford to maintain their own homes with servants, although well into their 70's and $80^{\circ}$ s.

To the latter group belonged a Mr \& Mrs D. He had been a member of the City Council and a former Mayor. She had played her part in civic affairs. This couple, when they had bought their home about 40 years ago, were then regarded as prominent citizens. Eventually servants became more difficult to employ due to the fact that the older servants had died and the younger ones were alien to their employers. New servants also did not wish to look after 2 old people 24 hours a day. Mr \& Mrs D. had children who were very good to their parents and showed a great deal of concern about their welfare. The children however were all married with families of their own and found it very difficult to look after Mother and Father other than visiting them daily, besides running their own lives. After a great deal of motivation from the children and with the help of our Department, the couple was eventually persuaded to enter an Old Age Home where they are still living together and are very well settled and happy.

I have learnt that romance never dies and one is never too old for a romantic attachment. Mr \& Mrs C. were 85 and 79 years old respectively. He was and still is slight and very spry. She was an invalid since I first met them 3 years ago. Illness took her in and out of hospital and made her increasingly fragile. Their only daughter was killed in a motor accident and although they had a son-in-law and 2 grandchildren who were married, they refused to live with any of these relatives and insisted on living alone. They lived in a part of the city which was regarded as a slum area and which is being demolished to form part of an urban renewal scheme eventually. Their income was only the State pension, with the aid of gifts from relatives donated as their generosity moved them. Their home was a semi-detached dwelling with 2 rooms and a kitchen. The bathroom and toilet were outside. There was electricity but no hot water. This couple lived near the hospital and so were able to attend the out-patients section regularly. Mrs $C$. had an indwelling catheter. I often found her up when feeling well, walking around with a urine bag attached to her leg. Under conditions such as these, the husband kept the home clean and his wife bathed and fed with the help of a part-time servant who came in 3 times a week.

Last year Mrs C. died. Her husband consoled himself that he had cared for her and loved her for about 60 years. They had 2 long-haired terrier dogs and a cat which now kept him company. He kept himself busy by playing the Jackpot at the racecourse and feeding the animals and himself. A part-time servant was employed on a once-a-week basis. Mr C. complains of difficulty in walking due to pain in the upper thigh of his right leg. He uses a walking stick but is not very mobile. A niece and her husband come to see him regularly and have begged him to live with them. He is almost aggressive in his refusal to move out of his home. His mind is alert and some of his "pals" often come in and play dominoes with him. We were instrumental in having the "Meals on Wheels"' Service call regularly. 
We also visited him regularly to ensure that he was still coping. However his big complaint and outcry was "I am lonely".

Six months ago this 86-year-old gentleman placed an advertisement in the Personal Column of the Sunday Times looking for a wife and companion. Despite the fact of his age and his address, I was surprised at the numerous replies he received from various women. These ladies ranged in age from 40 years to 70 years. All wished to meet him and were willing to come to his home. He chose a 68-year-old widow from Kempton Park. She came to visit him with her own car and chauffeur. Romance blossomed and $\mathrm{MrC}$. will be marrying her early this year. He will be moving to her home which, I gather, is comfortable as she is financially secure. As for this 86-year-old gentleman I hope he will spend the rest of his days happily and be content. As he says to me with a twinkle in his eye, "God has listened to my prayers, Sister, and I can still make a woman happy",

Our future is often seen as the unknown, fraught with dangers of ill health, lack of financial security, love and companionship. How much more so is this not the case amongst the citizens getting on in years, and who will soon be replaced at work by younger persons.

I first met Mrs S. about 7 years ago when she brought her daughter to our antenatal clinic. This daughter was having an illegitimate baby and the father did not wish to marry or be tied down as a father/husband.

Mrs S's granddaughter was born in our local hospital and apart from the emotional trauma everything else went according to plan. The daughter went back to work and Granny became the baby's mother-substitute. Elderly parents who should have been providing for their own old age, now had a baby in the home who needed love, care and financial support.

Eventually the daughter married the father of her child, but by now the grandchild was more attached to her grandparents than to her own parents. The young couple also were not very secure financially and thus often turned to the grandparents for help. The young father took to drink and drugs and was often out of work. By this time a second baby was on the way. After a few more stormy years the young father pulled himself together and stopped drinking. He now has a steady job and with moral support from the grandparents, the young family seem to be living a normal family life.

$\mathrm{Mr}$ and Mrs S. have 2 other sons who although able to manage their own homes, cannot assist their parents or sister financially. MrS. has now reached retirement. They have a paid-up home in a middle class area, but very little money in the bank. His employers have retired $\mathrm{Mr} \mathrm{S}$. on a pension of R25 per month. Mrs S. has no income whatsoever. On Mrs S's retirement, their Medical Aid has fallen away. Mrs S. needs continual medication for hypertension.

Both Mr \& Mrs S. were brought to our Preventive Geriatric Clinic. We referred them to the Department of Social
Welfare and Pensions despite the fact that they had been told by friends that they would not be eligible to get State Pensions as they owned a house. A trouble shared is a trouble halved. How happy they were to discover that they qualified for State Pensions.

This episode proved the saying:

" $40 \%$ of the things you worry about never happen

$30 \%$ are beyond your control

$12 \%$ will continue to happen even if you go on worrying

$10 \%$ was none of your business in the first place

The remaining $8 \%$ you face as courageously as you can."

Now as old age pensioners they are entitled to free medical attention from the District Surgeon and Provincial Hospital, free bus tickets locally and very reasonable holiday accommodation at holiday homes for senior citizens inland and at the coast.

Very often communications break down between parents and children through thoughtlessness and due to the pressures of living in our world today. This happens at all ages.

The Sister-in-Charge of the local hospital out-patient department phoned me and asked me to visit a 68-year-old widow living with her daughter. It was during December and Mrs L. had been brought into the out-patient department after taking an overdose of barbiturates in an attempt to commit suicide. This lady was attractive and well groomed but very unsure of herself. She has 3 married daughters. The one with whom she was living was in the throes of being divorced and had 3 teenagers in the home and at times lifc was chaotic. What with quarrels between the parents and noisy disco sessions emanating from the children and their friends, life for Mrs L. had become more than she could cope with.

Our patient was introduced to our local Service Centre where she met and made friends of her own generation. She moved out of her daughter's home and into a flat of her own. Being on her own in a commercial building was not very satisfactory. Her neighbours were working folk and she was often alone during the day. She now attends our psychogeriatric clinic. Medically she is attended to adequately. She has moved and is now living with another daughter and appears to be happy but still hankers to be more independent.

Mrs L. will be one of the first aged to move into a flat at a new complex which the City Council is building. Here all the occupants are pensioners. The Service Club is in the same grounds and meals will be available at a low cost. Socially too she will be catered for. Mrs L. realises her children do care and love her and are not only willing but anxious that she be happy.

During the last 3 years that I have been privileged to work amongst the senior citizens of our city I find I have altered my ideas of the aged although this section of the community can at times be trying and difficult to deal with. Each and every one of them have lived a life full of experiences from which all could gain. "I shall pass this way but once. Any good that I may do, let me do it now, for I shall not pass here again." 